\title{
The Interplay of Health, Pleasure and Wellness in British Seaside Resorts: the Case of Skegness on the Lincolnshire Coast
}

L'interaction de la dimension santé, plaisir et bien-être dans les stations

balnéaires Britanniques: le cas de Skegness sur la côte du Lincolnshire

\section{Mohamed Chamekh}

\section{CpenEdition}

\section{Journals}

Electronic version

URL: http://journals.openedition.org/rfcb/4330

DOI: $10.4000 /$ rfcb.4330

ISSN: 2429-4373

Publisher

CRECIB - Centre de recherche et d'études en civilisation britannique

\section{Electronic reference}

Mohamed Chamekh, «The Interplay of Health, Pleasure and Wellness in British Seaside Resorts: the Case of Skegness on the Lincolnshire Coast ", Revue Française de Civilisation Britannique [Online], XXIV-3 | 2019, Online since 30 August 2019, connection on 04 September 2019. URL : http:// journals.openedition.org/rfcb/4330; DOI : 10.4000/rfcb.4330

This text was automatically generated on 4 September 2019

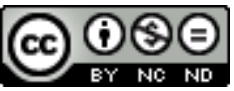

Revue française de civilisation britannique est mis à disposition selon les termes de la licence Creative Commons Attribution - Pas d'Utilisation Commerciale - Pas de Modification 4.0 International. 


\title{
The Interplay of Health, Pleasure and Wellness in British Seaside Resorts: the Case of Skegness on the Lincolnshire Coast
}

\author{
L'interaction de la dimension santé, plaisir et bien-être dans les stations \\ balnéaires Britanniques: le cas de Skegness sur la côte du Lincolnshire
}

Mohamed Chamekh

\section{Introduction}

Water has been used as a source of therapy for centuries especially at times when old medicine was not effective as a cure for all ailments. Greek doctors started as early as 460 B.C. to 370 B. C. to recommend baths in waters high in Sulphur to treat diseases. The Romans used balneotherapy ${ }^{1}$ for the treatment of diseases, ${ }^{2}$ and it was under the latter that baths were widely used for therapeutic purposes.

In Britain, the inland spas were the first health resorts. They were a destination for invalids to drink the waters of the springs. Bath was the most prominent inland health resort which appeared in Roman Britain. From the late sixteenth century, Bath started to attract health seekers and became the leading spa resort in Britain. ${ }^{3}$ Within the same tradition, other inland resorts like Cheltenham, Buxton, Harrogate, Tunbridge Wells and Woodhall joined Bath as health destinations.

In France, water was used for treatment even in colonies. Colonies like Tunisia, Madagascar and Guadeloupe were sites of mineral spas which were appropriated by colonists for their use as sites to treat colonial diseases while Vichy, a spa town in France, was used for cleansing from colonial diseases and the re-integration into French civilisation. ${ }^{4}$ 
However, the way waters were used and the type of waters saw constant changes. These changes were concomitant with changes in medical terminology that characterised the use of waters for therapeutic purposes. In this regard, terms like aqua therapy, balneology, hydropathy, etc. appeared in response to changes in the use of waters for treatment.

A major change was the use of seawaters for the treatment of diseases as many from the medical profession started to encourage their patients to visit seaside resorts for the treatment of diseases. Whole towns developed in response to an expanding number of visitors who took the waters in the quest of good health. In this regard, it needs to be mentioned that the growth of the seaside health resort was part of an overall context which considered nature as "curative".

Another aspect of the use of the seaside for health treatment was hydropathy which developed in the nineteenth century as an aspect of health establishments in seaside resorts. There were hydropathic institutes in many British seaside resorts where visitors stayed in metal rooms with compressed air. This air was meant to boost the oxygen levels in the body and at the same time clear "the air passages". ${ }^{\circ}$

The importance of seaside resorts for a better health was partly driven by a growing stress on lifestyles and climates as factors contributing to health. This tendency was strengthened by an all-inclusive health strategy adopted by the Ministry of Health, established in 1919, which sought to combine preventive medicine, lifestyles, and better health care provision to improve the health of British citizens. ${ }^{7}$

British seaside health resorts have been the focus of seaside resort history ${ }^{8}$ and partly tourism history ${ }^{9}$, but their mention as sites for treatment was in the context of seaside history rather than a detailed analysis of the evolution of these resorts as sites for the health improvement or maintenance apart from few studies like Gilbert (1939), who focused on the economic and the demographic development of coastal and inland health resorts ${ }^{10}$ or Hassan (2003) whose focus was not on the seaside resort as a site of health per se, rather Hassan dealt with the seaside environment in general including recreation, pollution, the socio-economic factors influencing the development of seaside resorts, and the seaside resorts as a liminal space. ${ }^{11}$ However, the development or the prospective development of British seaside resorts as sites of wellness or as sites for the improvement of the "quality of life" ${ }^{12}$ remains understudied. ${ }^{13}$ This is highly relevant especially with the growing concerns over the health needs of an ageing population and the challenges that should pose to the resources of the NHS and the constant decline of British seaside resorts as holiday destinations.

This article seeks to address the following questions: how did Skegness, a British seaside resort, develop into a health seaside resort? Why did it change into a working-class playground? And especially: is it possible for Skegness to develop into a wellness, which in turn would reduce the strain on the NHS if the British population were healthier?

\section{The growth of Skegness into a health resort}

The development of Skegness into a health resort was mainly premised on the importance of seaside waters form treatment. Skegness waters were recommended to relieve different disease conditions. Lord Dawson of Penn, a royal physician, considered Skegness to be "the healthiest place in England" when recommending it to a patient from 
Nottingham..$^{14}$ The accompanying text to an advertising poster in the Skegness local library, dating back to 1880 , lauded this resort as healthy and salubrious with perfect sanitary arrangements and unequalled water quality.

The health dimension of seaside waters was not specific to Skegness, but was common for all seaside locations. From the middle of the eighteenth century doctors started advising their patients to visit the seaside for health purposes. ${ }^{15}$ Being beside the seaside, plunging into the sea, walking by its side or drinking its waters were considered of health recuperative values. ${ }^{16}$ Seaside resorts took over the role of the inland spas like Bath, Harrogate, Tunbridge, Epsom, Scarborough, and Buxton. Hence, the bathing practices in the early seaside bathing places followed similar practices as those in the inland spas. Bathers were, for example, dipped in sea waters for health recuperative purposes, a practice which was common in inland watering places. ${ }^{17}$ Resorts were considered by Rob Shields (1988) in this era as "clinics", and he labelled Brighton between 1730 and 1820 as " clinic Brighton". ${ }^{18}$

The use of seaside waters for therapeutic purposes was strengthened with Dr Richard Russell's recommendation of the use of seawater for the same purposes as the inland spa. In 1747, he published De Tabe Glandulari, which was translated as A Dissertation concerning the use of Sea-Water in diseases of the glands, in which he recommended the use of seawater for the treatment of consumption, cirrhosis, leprosy, gonorrhoea, scurvy, languor, epilepsy and so on. Dr. Russell, for example, recommended to one of his patients drinking "half a pint of sea water every morning at five of the clock". At the same time, he considered cold sea bathing a prerequisite for a "great quiet of body and mind" and advised patients to drink a glass of sea water immediately after coming out of the sea. ${ }^{19}$

Dr. Russell's Dissertation played a significant role in the spread of the cult of sea bathing for therapy purposes and henceforth the growth of seaside resorts to the extent that he was considered "the father of all seaside watering places". ${ }^{20}$ Many places in Brighton bear the name of Dr. Russell (Russell Street, Russell Square, Russell Place) in recognition of the role he played in the growth of this seaside resort. Russell used for example to recommend Brighton for his patients when he was a practicing physician at Lewes. ${ }^{21}$ It was in this era that the sea water of Brighton was bottled and sold as medicine in London. ${ }^{22}$

Sea bathing soon became a health vogue which gained momentum with the visits of members of the royal families to the seaside for medical treatment. Acting on the advice of his physicians, the Prince of Wales, for example, visited Brighton in 1783 for the treatment of his glands. ${ }^{23}$ Similarly, the recovery of George III from a supposed attack of insanity was accompanied in 1789 with a long stay in Weymouth. ${ }^{24}$

Skegness followed the same developmental lines of the seaside resorts in England. It was referred to in early Directories as a bathing place frequently visited by people for health purposes. ${ }^{25}$ Stress was laid in most of these Directories on the importance of Skegness as a bathing place and its health qualities. Skegness was visited by the local gentry and respectable families who used to stay in Skegness for "sometime" ${ }^{26}$ mainly for health purposes. For this purpose, bathing machines were stationed in Skegness. These machines were meant to hide the body of the bather from observation and give the bather the chance to enjoy the pleasure of a plunge in sea waters, but in a way which " protect[ed] modesty' and did not violate the norms of public decency. ${ }^{27}$ These machines were mentioned in Skegness in William White's 1842 History Gazetteer and Directory of Lincolnshire, ${ }^{28}$ but they existed earlier. ${ }^{29}$ Similarly, Avery's Penny popular guide to Skegness (1884) pointed to forty bathing machines which were stationed on the beach of Skegness. 
${ }^{30}$ The presence of these machines in Skegness showed to a certain extent that the visitors to Skegness used to follow the norms of order, decency and respectability and a plunge in sea waters, sea air and a gaze at the sea were the major attractions of Skegness.

As a health resort, Skegness saw the expansion convalescent homes specifically for its recuperative health qualities. The Hampshire advertiser referred in 1885 to Lady Scarborough's orders for the building of a convalescent home on her son's estate for children in Skegness. ${ }^{31}$ The 1900 Kelly's Directory pointed to the Nottingham and Notts Convalescent Home for Men at Seathorne and a similar one for women at Castle Donington, ${ }^{32}$ and Dutton's Directory of Skegness (1934) referred to the Derbyshire Miners and Friendly Societies Home, which was established by the Miners' Welfare Fund in 1926, Nottingham Poor Girls Camp Society, Lady Scarborough Convalescent Home, National Deposit Friendly Society, and the Lewison Convalescent Home, and Boots Convalescent Home. ${ }^{33}$ The frequent reference to convalescent homes in Skegness showed the image Skegness accrued as a health resort and a major destination for health seekers.

The growth of Skegness as a health resort was clear in holiday guidebooks of the nineteenth century and the first half of the twentieth century. Avery's 1889, 1894, and 1898 Guidebooks of Skegness stressed the importance of Skegness for health. His 1889 and 1894 Guidebooks pointed to the fact that Skegness was "a health- restoring place". ${ }^{34}$

In addition to the sea waters, the drinkable water of Skegness was considered of organic purity and of "first class quality". ${ }^{35}$ The quality of water and the installation of an efficient sewage system made all conditions in Skegness "favourable for healthfulness". ${ }^{36}$ While highlighting both the quality of water and the drainage system in Skegness, The Sheffield \& Rotherham Independent (1880) wrote:

Skegness is provided with two very important elements, viewed from a sanitary point of view, so essential to the wellbeing of any town, and particularly one of this description to which thousands annually resort for the purpose of recruiting health. ${ }^{37}$

These aspects (sanitary arrangements and the quality of water) were stressed in other newspapers of the $1880 \mathrm{~s}^{38}$ something which could be explained by the importance of the quality of water and the sanitary arrangements in all ages for health.

The focus on health continued in the first half of the twentieth century. The publisher of Picturesque Skegness (C 1900) considered Skegness a "well established seaside health resort". ${ }^{39}$ Similarly, the opening pages of the Guide to Skegness and Wainfleet (1925) referred to " invalids and persons seeking health" as among the frequent visitors to Skegness. ${ }^{40}$ The importance of Skegness as a health resort was brought to the limelight through a conference on "Healthy Holidays for the Worker", which was held in Skegness in 1937. Speakers at this conference underlined the health restorative values of seaside health resorts. Dr. R. Cove, for example stressed the effectiveness of sea bathing for the promotion of a "healthy vascular coordination". Similarly, Dame Louise Mcllroy addressed the conference on the treatment of gynaecological affections at seaside health resorts. ${ }^{41}$ The organisation of this conference in Skegness showed the continuing importance of Skegness as a health seaside resort at least till the late 1930s. 


\section{Healthy air of Skegness (1840-1970s)}

In addition to the waters of Skegness, the air of Skegness was considered of health recuperative values. A visitor to Skegness described the healing qualities of the Skegness air as follows:

Farewell, wide expanded ocean,

Boundless source of calm delight

All thy breezes health inspiring

Lent new vigour to this frame. ${ }^{42}$

This poem illustrates the way visitors considered their journey to Skegness in the early nineteenth century. A journey which was both therapeutic and at the same time a source of re-invigoration. Similarly, While referring to the health qualities of Skegness air, the holiday correspondent of the Standard (1885) stated that it "must be pronounced bracing enough to satisfy the most robust invalid". ${ }^{43}$ In addition, while describing the elements that made Skegness a health seaside resort, the 1889 Avery Guidebook considered Skegness air to be one vital aspect of these. ${ }^{44}$ The same element was described in the 1894 Guidebook as 'so pure' and contained a large amount of ozone, which was seen as a "mysterious health giving element". ${ }^{45}$ The same feature was stressed in Seaside Watering Places (2/6) (1888). " Skegness has", according to this guidebook of seaside health resorts in England and Wales, "what is infinitely more essential to invalids and seekers after quiet and health in its bracing air and salubrious ozone laden atmosphere" ${ }^{46}$ The dictionary of Watering places (1881) gave a similar depiction of the Skegness air. ${ }^{47}$

The air of Skegness was further stressed with the decline of confidence in the importance of sea waters for treatment. According to the 1926 Skegness Holiday Guide, if you wanted relief from asthma, bronchial complaints, or neurosis, visiting Skegness would be the solution. "Af "After a few days" of visiting the resort, the Skegness Official Guide Book (1926) stated, "the bracing air and atmosphere relieves [sic] those sudden paroxysms of difficult breathing, and the tightness of the chest diminishes". ${ }^{49}$ The writer of this Guide Book (1926) pointed to his own experience with Skegness, presenting a testimony to the fact that he visited Skegness when he suffered from glands and he was relieved after a short stay there. He stated that 'the supreme thing about the place remains the quality of its air. The best advertisement for this Lincolnshire resort would be to put a taste of atmosphere in small liqueur bottle... The most anaemic city clerk, after a sniff at that bottle would feel capable of getting up and hitting Dempsey. ${ }^{50}$

In a similar vein, the cover page of the Skegness Holiday Guide of 1931-32 was full of references to the healthfulness of Skegness. It pointed to Skegness as the "Home of Health" and described the place as "bonny" and "bracing". A brief search for the meaning of both words in the Oxford English Dictionary shows an association between these two and health.

Skegness continued to be classified as a health resort in the 1930s. In this context, The Times section on weather continued to refer to Skegness as health resort in the 1930s, ${ }^{51}$ and the 1936-1937 Holiday Guide Book called on "busy longshoremen" and shipmates to benefit from the weather of Skegness for invigoration, freshness and fitness. ${ }^{52}$

The stress on the bracing air of Skegness, but to a lesser extent its healing qualities, continued in the second half of the twentieth century. ${ }^{53}$ This could be explained by the fact that this 'commodity' was abstract and hence did not require on-the-ground expenditure. The focus on sea air, as an aspect of the health bringing qualities of seaside 
resorts, was, according to John Beckerson and John K. Walton (2005), "accessible, free and pleasant". ${ }^{44}$ It could also be explained by a continuation on the stress on health and healing as major attractions of this holiday destination. ${ }^{55}$ However, with the inflow of working class excursionists and especially during the golden years of mass tourism, skegness changed from a health seaside into a working class playground.

\section{A working-class playground}

Skegness, despite the continuing emphasis on its healthy climes, changed into a workingclass playground. The railway led to gradual change in the social constituency of the visitors to Skegness by bringing the industrial workers from the East Midlands, Yorkshire, and London..$^{56}$ This type of visitors started to gradually replace the existing 'well to do' visitors..$^{57}$ The extension of the railway to Skegness on July 28,1873 served as a catalyst for this change, especially as this date was convenient for workers to visit Skegness because it was followed by the August Bank Holiday (the first Monday of August), from Lubbock's Act of 1871, entitling workers to a day's holiday.

Railway Excursions to Skegness coincided with the second and third phases of railway excursions to resorts, which were respectively in the 1870 s, 1880 s, and $1890 \mathrm{~s} .{ }^{58} \mathrm{In}$ comparison with the first phase (in the 1840's), in which the working class holidays were still in their formative stages and the number of trippers was small, the last two had a serious impact on resorts because the demand for working class holidays was higher. ${ }^{59}$

Benefitting from the railway nominal fares ( 3 shilling), ${ }^{60}$ and the rise in real wages in the closing decades of the nineteenth century, workers arrived in special trains from Lincoln, Nottingham, Derby, London (King's Cross) and East Midlands industrial towns in general. In Lincoln, workers made use of their foundry trips holiday, a four day holiday at the end of July granted by employers to foundry workers to improve their performance, and organised railway trips to Skegness and other resorts on the East Coast. ${ }^{61}$ To benefit from this holiday, workers in Lincoln, and in other parts of England, got involved in saving schemes through Friendly Societies, Mechanics' Institutes, Sick and Dividing Clubs, saving schemes at work, political groups and even in streets. ${ }^{62}$

A comparison between the early railway excursions, which were organised to exhibitions by working class organisations like the Mechanics' Institutes and Friendly Societies, and those organised by railway companies to the seaside revealed a major difference in the purpose of each. While the organisers of the former were motivated by the improvement of the health, the culture and the personal improvement of the worker through rational recreation, ${ }^{63}$ the latter were mainly driven by profit. ${ }^{64}$

The sheer number of excursionists to Skegness and their socio-economic profile led to the change of the social outlook and the tone of this seaside resort. Describing the excursionists from Lincoln, mainly the foundry workers who used to frequent the Lincolnshire resorts (Skegness, Cleethorpes and Mablethorpe), Lorna Nicholls (1978) stated that they were "weary people from the smoke-laden air of the streets of the city and the mean little houses which clustered around the foundries". ${ }^{65}$ The change in the socio-economic profile of the visitors to Skegness was clear in the behaviour of the 'new' visitors. This led to the 'departure' of the long staying middle class families, especially those who looked for health and especially relaxation and quietude, in search of select seaside resorts, especially as the social mores brought by the working class visitors conflicted with norms of respectability and gentility that made many of these families 
choose Skegness for a holiday before the arrival of the railways. This was the case with all seaside resorts which were accessible in terms of money and fares to the workers of industrial towns. ${ }^{66}$ In Brighton, for example, Queen Victoria did not return after 1843 when she found that its inhabitants had become "very indiscreet and noisy" ${ }^{67}$ The middle class left later to quieter resorts in search of "health-giving pleasure". ${ }^{68}$

The change of the socio-economic profile of the visitors to Skegness led to a class conflict between those seeking health giving recreations and a wide section of the working class who sought to fully exploit their free time regardless of health or rational recreation. Being temporarily freed from the factory discipline, workers used to sing, dance, and specially drink until late. In this context, it seems relevant to point to a study by Dingle (1972) on "Drink and working-class living standards in Britain, 1870-1914" which coincided with the era of the excursion trains to Skegness. Dingle found that workers in this era spent most of their money on beer and spirits consumption. Dingle considered workers not morally prepared for the pay hikes and leisure time ${ }^{69}$ as the brief liberation of the workers from factories led to their indulgence in drinking and 'noise and bustle' in general. ${ }^{70}$ This issue continued in the first half of the twentieth century, something which made police superintendents in some resorts enlist the help of the licensees so as to reduce drunkenness and maintain order. ${ }^{71}$ Murray's Handbook for Lincolnshire (1890) described Skegness after the invasion of trippers from Lincoln, Nottingham, and Derby as "the noisiest and most crowded of the Lincolnshire seaside places, except Cleethorpes" and concluded with the fact that it was not recommended for "quieter visitors". ${ }^{22}$ Similarly, a local newspaper likened Skegness after the visits of masses of excursionists to Skegness in the August Bank Holidays of 1882 to Egypt after an invasion of locusts. ${ }^{73}$ These years saw the gradual departure of the middle class families in search of resorts which were not in the reach of the excursionists and the working class holiday makers especially during workers' holidays.

In light of the role the railway companies played in bringing workers to Skegness, it seems safe to say that the railways changed Skegness from a health resort into a workingclass pleasure playground. This was despite its remoteness, as there were remote resorts, such as in East Anglia, West Wales, and the West Country, that managed to preserve their exclusivity and which remained exclusive because of their remoteness. ${ }^{74}$ On the contrary, Skegness was appropriated by the working class. It became their holiday sphere and their zone of escape from the factory system and routine, something which was clear through the spread of working-class amusements in this resort.

One main aspect of the transformation of Skegness into a working-class seaside resort related to working class amusements and patterns of consumption which adapted to the needs of the new visitors and showed the attempts to profit from mass tourism. In this regard, this era saw the spread of fish and chips restaurants in Skegness. Though it was a major component of the working class diet, the new fast food of the early years of the twentieth century became a main feature of working class popular culture. ${ }^{75}$ Referring to the spread of the fish and chips trade in Skegness, Winston Kime ironically pointed to the possibility of naming Skegness High Street Dyson's Street after the Oldham trader who started the fish and chips 'industry' in England..$^{76}$ This was concomitant with the spread of huts on the beach selling tea, beer, coconut, and shellfish as part of an overall attempt to adapt to the changing socio-economic profile of holidaymakers.

Amusements could be used to decipher the transformation of the resort from a health resort into a working-class playground. The resort amusements were among the 
parameters Harold Perkin mentioned for the classification of seaside resorts. For Perkin, there should be a distinction between amusements like indoor baths, classical concerts, art galleries, and museums, and amusements like brass bands, donkey and pony rides, beach entertainers, and catch penny amusements. ${ }^{77}$

A comparison of publicity of the early stages of resort development with those of the second half of the twentieth century revealed a shift towards amusements as the main attractions of Skegness. Guidebooks changed their shift from the resort natural landscape in tune with the visitors' quest for health to the resort open air amusements like donkey rides, shooting galleries, gambling, festivals, galas, gambling, and bingos. Similarly, there was a major change towards the artificial and the show type. Skegness was converted in the guidebooks of the second half of the twentieth century into a giant theme park. This could be noticed through the changes in guidebook captions, which considered Skegness to be "Britain's Famous Holiday Playground" (1963), the "passport to pleasure" (1978), or the " giant theme park with non-stop fun" (1981). These captions replaced the focus on the health dimension of Skegness in most references to Skegness both in directories and early guidebooks of Skegness.

The importance of Skegness as a health seaside resort declined sharply with the transformation of Skegness into a working-class pleasure resort with the inflow of working-class excursionists to the resorts. This change was the result of the inflow of excursionists, and at the same time the growing popularity of biomedicine and the success of technology and laboratories from the mid-nineteenth century ${ }^{78}$ which affected the image of seaside resorts as health destinations. Nevertheless, "the healing power of nature" 79 has recently come to the limelight with the renewed emphasis on seaside resorts as sites for wellness and health maintenance.

\section{Skegness: A potential wellness resort}

Skegness, in light of the changes in the tourism industry, seems well situated to benefit from wellness tourism. The stress on the development of wellness tourism in Skegness derives from the development of a new type of tourism worldwide which seeks to attract tourists seeking wellness. This type of tourism promotes physical exercise, intellectual development and relaxation which should lead to a balanced body, a relaxed mind and a better spirit..$^{80}$ It is difficult to define wellness tourism. Oxford English Dictionary defines wellness as the

the state or condition of being well or in good health, in contrast to being ill; the absence of sickness; the state of (full or temporary) recovery from illness or injury [and] the state or condition of being in good physical, mental, and spiritual health, esp. as an actively pursued goal; well-being. ${ }^{.1}$

As it might appear from this definition, wellness is all-inclusive. It encompasses the mental, the physical and the spiritual. This definition is in tune with Kelly's definition who considered wellness as the result of "a balance between wellbeing in the body, the mind and the spirit". ${ }^{82}$ Similarly, for Edward H. Huijbens (2011), the difference between health and wellness lies mainly in the fact that the former is a state of being while the latter is defined by its purpose which is the improvement of the state of the body, the soul and the mind. ${ }^{83}$

Wellness tourism, however, is considered as a "subset of health tourism". ${ }^{84}$ Sometimes, it has to do with other activities not necessarily related to treatment, but with a purpose of 
maintaining health. As a result, activities like physical exercise, massage, consumption of healthy food, were considered wellness activities ${ }^{85}$ This type of tourism is considered a niche market at the global level, ${ }^{86}$ which is gaining momentum.

Wellness tourism could regenerate Skegness and seaside resorts facing major economic problems which is the case of most seaside resorts in Britain. ${ }^{87}$ Stephen J. Page et al., (2017) stressed the way wellness tourism could boost the fortunes of declining seaside resorts. They highlighted in particular the way the old mass tourism seaside resorts could develop into wellness destinations by combining both health and pleasure. They focused in particular on the way well-being tourism should be used to regenerate old seaside resorts especially through the development of small businesses, mainly those meant for health maintenance or promotion, which should combine both well-being and health which would in turn boost the economy of the UK coastal resorts. ${ }^{88}$

\section{The UK government's wellness strategy and the potential transformation of Skegness into a wellness resort}

Time seems opportune for the transformation of Skegness into a wellness resort especially with the central government and the NHS's emphasis on wellness as a way to prevent diseases. This was stressed in the 2018 government health vision which highlighted prevention as the government health approach. Matt Hancock, Health and Social Care Secretary, outlined this vision in his foreword to the government document on health and social care, in which he considered prevention as the best way to save lives. ${ }^{89}$ The new recurrent message is "one of being, or becoming more 'well' and, by implication, fitter, happier, and more productive".$^{90}$ Despite the constant decline of preventive health spending to local governments from 2009, ${ }^{91}$ the discourse related to wellness continued to rank high on the government health policy agenda.

The transformation of Skegness into a wellness resort could be facilitated by the need of employers (business, industry, government) to control the cost of health care services by opting for strategies that would help them prevent diseases or reduce stress levels among employees. ${ }^{92}$ This is a major change in comparison with the era of the Industrial Revolution when holidays were considered a preparation for a new cycle of work, a relief from work and a short term recovery, while the new challenge is to "keep the workers fit and productive" 93 to prepare them for long term endurance. This change was clear even within the NHS especially with the growth of NHS Trusts among the employees of many healthy establishments under the NHS that stressed wellness among employees. For example, York Teaching Hospital NHS Foundation Trust started a project that was meant to reduce absences from work, prevent diseases and ensure immediate intervention, which was part of an overarching program meant to 'manage staff health and wellbeing' and an all-inclusive approach to health which took into consideration aspects like lifestyles and environments as factors impacting on employees. ${ }^{94}$ This was the case with other NHS Trusts like South London and Maudsley NHS Foundation Trust, whose main objective was "to reduce the stress its staff were feeling within the workplace and to increase staff happiness and wellbeing so that they could continue to provide the best care for patients". ${ }^{95}$

Skegness could benefit from the Wellbeing Saturdays organised by the NHS Trusts for its employees by offering tourist services meant to boost the wellbeing of visitors seeking 
relaxation and physical activity. ${ }^{96}$ This could then be extended beyond this institution to other companies and institutions on a national basis. Skegness local Council could invest in wellness holidays in the fashion of the weekend and off-season holidays which developed in England in the 1980s and 1990s. This could be done in direct partnership with local governments who are now responsible for preventive healthcare or with local NHS Trusts, especially as some Trusts started initiatives with councils like Nottingham City Council to develop cycling initiatives and at the same times arrange events, like the National Bike Week, which were generally meant to encourage physical activity and boost the wellness of the employees. ${ }^{97}$ Wellness holidays could give a boost to Skegness especially out of the traditional summer holidays. This, however, does not preclude the fact that Skegness and other resorts in Britain need to cope with major challenges like competitive destinations abroad where holidays are cheaper, facilities better, and especially a more salubrious weather.

Skegness local Council and the East Lindsey District Council could play a pivotal role in changing Skegness, in cooperation with local authorities, into a wellness destination especially with the increasing emphasis on the role of the latter in the development of appropriate health strategies. This was clear in the 2010 address by the Secretary of State for Health who focused on localism that was considered at the core of the new health care system. In this regard, he stated that "by giving local government control of public health resources, we will shift power and accountability to local communities and create healthy places with new partnerships in important areas" ${ }^{98}$ which will help in addressing major problems such as depression and other health problems. This could be facilitated by the establishment of the wellbeing boards which should bring in the expertise of the NHS and public health leaders in each area to better address the health needs in each area. ${ }^{99}$

Skegness could be a prospective site for wellness tourism especially with the steady flow of the elderly to the resort. This is very relevant to Skegness which has seen a constant flow of elderly people to the resort from the late twentieth century and continued into the twenty first century. The percentage of people aged over sixty-five, among the residents of Skegness, was found in a study by Jane Atterton above the national level. This age category made 22.2 per cent of the population of Skegness in comparison with 16 per cent at the national level. The situation was similar in the early twenty first century in other coastal resorts. For example, the median age in coastal communities was higher than the median age in Great Britain in 2001 and comprehensibly the percentage of the elderly in coastal towns was higher than their percentage in Great Britain and made almost one quarter of the total population of coastal towns. ${ }^{100}$

Skegness local authorities even called on old people to visit the resort. This was clear in a guide book of the late twentieth century (1995) where the language used seemed to avoid the use of the word old or elderly possibly in a bid to appeal to this age category. According to a 1995 guidebook:

Skegness has a reputation as a resort for all the family and the young and not so young are all catered for here. The popularity of the resort to the less able is obvious. The flatness makes it an ideal resort to everyone, there are gardens to explore, a quiet game for of bowls, the model village to delight the eye, and of course the numerous cafes to relax in and watch the world go by. Come and enjoy a well-earned rest. ${ }^{101}$

As it might appear from this passage, it is true that there was a call to old people to visit the resort, but the problem is that the facilities and the recreations offered do not make of Skegness a place for people seeking health maintenance or wellbeing. In this regard, it 
seems sound to say that Skegness local authorities need to develop wellness facilities that could further boost the movement of old tourists to the resort.

Skegness Council should support the development of facilities like all-weather entertainment and wellness centres, clinics and even local clubs with wellness objectives, which could help in attracting tourists seeking wellness, in particular among the elderly generation, especially as the government's new health strategy seeks to prevent and manage physical and mental problems of an ageing population, which is expected to double by 2031 and should consequently pose serious challenges to local authority and NHS resources. ${ }^{102}$ In this regard, the Ministry of Health and the NHS have started promoting active ageing as a new strategy to prevent health problems, which according to the State Secretary of Health should be "the norm rather than the exception". ${ }^{103}$ This is, according to the Ministry of Health, part of an overarching strategy in which public health will be integrated with other areas like leisure so as to keep people "active and reduce isolation". ${ }^{104}$

Skegness, local authorities and the NHS should benefit from a partnership that should promote wellbeing of an elderly generation and at the same time regenerate Skegness. This is a need because the NHS is under continuing pressure to cater for the needs of an ageing population.

The local government and the NHS are faced with challenges related to the health needs of an ageing population whose health needs are increasing. In this regard, the local government and the NHS need to be more proactive as admitting people in hospitals would definitely cost more in comparison with the preventive measures that could lessen the financial burdens of medical treatment as the number of people aged 75 or above is expected to double by 2031. ${ }^{105}$

The location and the environs of Skegness make of this resort an ideal wellness destination for different age categories. The neighbouring Fens, the bracing air of Skegness, and the seaside could be re-packaged to attract tourists seeking fresh air, a space for physical exercise and relaxation. According to Page et al. (2017),

The natural attributes of the coast and its association with healthy living can now be repackaged and rediscovered within the wellness paradigm by tourism entrepreneurs. Coastal resorts have many natural advantages that can be harnessed with well-being linked to tourism so as to attract the increasingly ageing populations of the new millennia, many of whom may rediscover the coast in a new age. ${ }^{106}$

The health attributes of the coast have been given further momentum with studies which associated between the coast and better health. For example, a 2012 study by the European Centre for Environment and Human Health found that people who live close to the sea were more likely to be in good health even in the most deprived areas. Research by the same Centre recommended the coast for stress relief. ${ }^{107}$ Furthermore, analysis of the 2011 census found that some seaside resort, like Sussex for example, had more centenarians than anywhere in Britain and the sea air was considered as the secret for longevity. ${ }^{108}$ Therefore, Skegness and other coastal resorts need to develop new strategies of regeneration that stress health maintenance and wellness in seaside resorts. This is relevant despite the ongoing calls to make towns and the urban environment in general people-friendly, a quest which remains unaccomplished at least in the near future. ${ }^{109}$

Nevertheless, the transformation of the old seaside resorts into wellness destinations is not without challenges. For example, the changing of old tourist installations, mainly 
hotels, into wellness facilities is a daunting task especially as the accommodation sector, has so far failed to respond to the needs of a new clientele who found in resorts in the Caribbean and the Mediterranean state of the art facilities and hence they had higher expectations of local tourist resorts. This is mainly because of the heavy costs of restructuring and partly because of the lack of initiative or what Andrew Clegg considered as "inertia" ${ }^{110}$ Yet, skegness could change from a mass tourism destination centred on the notion of escape involving hedonism and all the attendant pursuits into a wellness destination focused mainly on stress relief, physical activity and personal development.

\section{Conclusion}

Skegness started as a destination for health, but the inflow of the excursionists and the developments in medicine changed the place into a destination for excursionists seeking escape from work through pleasure. However, with the changes in tourism and local and national government health strategies, the resort could benefit from a better infrastructure which should cater for a new type of tourists seeking escape, recreation, spiritual and physical wellbeing.

Mohamed Chamekh has a PhD in English Language and literature from the University of Rouen Normandy and is currently a lecturer at Ibra College of Technology, Sultanate of Oman.

\section{BIBLIOGRAPHY}

Adams, Jane M. "Healthy places and healthy regimens: British spas 1918-50", in Virginia Berridge and Gorsky, Martin (eds.), Environment, Health and History (London, Palgrave Macmillan, 2012).

Agarwal, Sheela and Brunt, Paul, "Social Exclusion and English Seaside Resorts", Tourism Management 27: 4, 2006, pp. 654-670.

Anonymous, Picturesque Skegness. (C. 1900). (Skegness, Ensor \& Ball, c.1900).

Anonymous, Skegness Official Guide, 1926 L. SKEG.91. Skegness Library.

Atterton, Jane, “Ageing and Coastal Communities," Report for the Coastal Action Zone Partnership Newcastle-upon-Tyne, Centre for Rural Economy. Newcastle University (2006).

Avery, John, Avery's Penny Guide to Skegness and Neighbourhood, with Map (London: Avery, 1894).

Ball, Geo, Sylvan Skegness (Skegness, Geo. F. Ball, 1932).

Barton, Susan "Why We're All Going on a Summer Holiday: The Role of the Working-class Organisations in the Development of Popular Tourism, 1850-1950" (PhD diss., De Montfort University, 1999).

Barton, Susan, "The Mechanics Institutes: Pioneers of leisure and excursion travel," Transactions (Leicestershire Archaeological and Historical Association) 67, 1993, pp. 47-58. 
Beckerson, John and Walton, John, "Selling air: Marketing the Intangible at British Resorts," in Histories of Tourism: Representation, Identity and Conflict, ed. John Walton, 88-70 (Clevedon, Channel View Publications, 2005).

Bingham, John, “Sea Air the Secret of Long Life as Census Shows Bexhill-on-Sea is Britain's Centenarian capital”, 25 September 2012, <https://www.telegraph.co.uk/news/health/ elder/9563327/Sea-air-the-secret-of-long-life-as-census-shows-Bexhill-on-Sea-is-Britainscentenarian-capital.html> [18 December 2018].

Borsay, Peter, "Georgian Bath: A transnational culture" in Peter Borsay and Jan Hein Furnée (eds.), Leisure cultures in urban Europe, c. 1700-1870 (Manchester, Manchester University Press, 2016).

Breitrück, Vivien and Nunn, Elena, "Health and medical tourism," in The Long Tail of Tourism, ed. Alexis Papathanassis (Germany, Gabler, 2011).

Carter, Simon "Leagues of sunshine: sunlight, health and the environment" in Virginia Berridge and Martin Gorsky (eds.), Environment, Health and History (London, Palgrave Macmillan, 2012).

Clegg, Andrew and Essex, Stephen, "Restructuring in Tourism: The Accommodation Sector in a Major British Coastal Resort”, International Journal of Tourism Research 2: 2, 2000, pp.77-95.

Department of Health, High Quality Care for All. NHS Next Stage Review Final Report. 26-27, June 2008, <https://assets.publishing.service.gov.uk/government/uploads/system/uploads/ attachment_data/file/228836/7432.pdf> [24 October 2018].

Department of Health, Healthy lives, Healthy People: Our Strategy for Public Health in England, Vol. 7985. (London, The Stationery Office, 2010).

Department of Health and Social Care, Prevention is better than cure: Our vision to help you live well for longer, 05 November 2018,

<https://assets.publishing.service.gov.uk/government/uploads/system/uploads/ attachment_data/file/753688/Prevention_is_better_than_cure_5-11.pdf> [28 February 2019].

Dingle, Anthony, "Drink and Working-class Living Standards in Britain, 1870-1914", The Economic History Review 25: 4, 1972, pp.608-622.

Durie, Alastair, “A Fading Movement: Hydropathy at the Scottish Hydros 1840-1939," Journal of Tourism History 4: 1, 2012, pp.57-74.

Dutton, George, Dutton's Directory of Skegness (Skegness, Dutton Printing Co, 1934).

East Lindsey District Council, Skegness, Ingoldmells and Chapet St. Leonards (East Lindsey District Council, 1995)

Gale, Tim, "Modernism, Post-modernism and the Decline of British Seaside Resorts as Long Holiday Destinations: A Case Study of Rhyl, North Wales", Tourism Geographies 7: 1, 2005, pp. 86-112.

Gilbert, Edward W., "The Growth of Inland and Seaside Health Resorts in England", Scottish Geographical Magazine 55: 1, 1939, pp.16-35.

Gill, Upcott, Seaside Watering Places: A Description of Holiday Resorts on the Coast of England and Wales (London, L. Upcott, 1888).

Gill, Upcott, The Dictionary of Watering Places: Seaside and Inland at Home and Abroad. (London, Upcott Gill, 1881). 
Gonzales, Anthony, Brenzel, Logan and Sancho, Jennifer, "Health Tourism and Related Services: Caribbean Development and International Trade," Final report (2001).

Gurnham, Richard The Creation of Skegness as a Resort Town by the Ninth Earl of Scarborough, n.d. Local and Family History, Lincoln reference and local Library, L. SKEG. 9.

Heywood, Abel, Guide to Skegness and Wainfleet (1925) (Manchester, Abel Heywood \& Son, 1925).

Hildebrand, Frey, Designing the City: Towards a More Sustainable Urban Form (London, Taylor \& Francis, 2003).

Huang, Liyuan \& Xu, Honggang, "A Cultural Perspective of Health and Wellness Tourism in China", Journal of China Tourism Research 10: 4, 2014, pp.493-510.

Huijbens, Edward H., "Developing Wellness in Iceland. Theming Wellness Destinations the Nordic Way", Scandinavian Journal of Hospitality and Tourism 11:1, 2011, pp.20-41.

Kelly, Catherine, “Analysing Wellness Tourism Provision: A Retreat Operators' Study”, Journal of Hospitality and Tourism Management 17: 1, 2010, pp.108-116.

Kelly, E. R., Kelly's Directory of Lincolnshire and Hull (London, Kelly Directories, 1889).

Kime, Winston, Skeggy! The Story of an East Coast Town (Skegness, Sashell Books, 1969).

Mackley, James and Mackley, Jennifer, Skegness through the Years: Skegness from an Agricultural Village to a Seaside Town (Skegness, U3A, 2005).

Majeed, Azeem, "Primary Care: A Fading Jewel in the NHS Crown", London Journal of Primary Care 7: 5, 2015, pp.89-91.

MCGillivray, David, "Fitter, Happier, More Productive: Governing Working Bodies through Wellness",

Culture and Organization 11: 2, 2005, pp.125-138.

Morgan, Nigel and Pritchard, Annette, Power and Politics at the Seaside: The Development of Devon's Resorts in the Twentieth Century (Exeter, University of Exeter Press, 1999).

Murray, John, Handbook for Lincolnshire, (London: John Murray, 1890).

Muzaffer Uysal et al., "Quality of life (QOL) and Well-being Research in Tourism," Tourism Management 53, 2016, pp. 244-261.

Nicholls, Lorna Mary, 'Beside the Sea' Concerning the Growth of the East Coast Resort around 1870 to the Beginning of the Second World War and the People Who Helped Them to Grow" (Diss. For the certificate of Local History, Bishop Grosseteste College, Lincoln, 1978) L. 91, Skegness Library.

Nottingham University Hospitals NHS Trust, "Excellence in Employee Wellbeing”, June 2015, < https://www.nhsemployers.org//media/Employers/Publications/HWB/HWBNottinghamJune-2015.pdf> [24 October 2018].

Nottingham University Hospitals NHS Trust, "Excellence in Employee Wellbeing”, June 2015, < https://www.nhsemployers.org/-/media/Employers/Publications/HWB/HWBNottinghamJune-2015.pdf> [24 October 2018].

Opatz, Joseph, Economic Impact of Worksite Health Promotion (Illinois, Human Kinetics Publishers, 1994).

Page, Stephen J. et al., "Case Study: Wellness, Tourism and Small Business Development in a UK Coastal Resort: Public Engagement in Practice,” Tourism Management 60, 2017, pp.466-477. 
Perkin, Harold, "The Social tone of Victorian Seaside Resorts in the North-West”, Northern History 11: 1, 1976, pp.180-194.

Pimlott, John Alfred Ralph The Englishman's Holiday: A Social History (Brighton, Harvester Press, 1976).

Robinson, David The Book of the Lincolnshire Seaside: The Story of the Coastline from the Humber to the Wash (Buckingham: Barracuda Books Limited, 1981).

Rodrigues, Áurea, Kastenholz, Elisabeth and Rodrigues, Apolónia, "Hiking as a Relevant Wellness Activity-results of an Exploratory Study of Hiking Tourists in Portugal Applied to a Rural Tourism Project", Journal of Vacation Marketing 16: 4, 2010, pp. 331-343.

Shaw, Gareth and Williams, Allan, The Rise and Fall of British Coastal Resorts: Cultural and Economic Perspectives (London, Mansell Publishing, 1997).

Shields, Rob, "Images of Spaces and Places: A Comparative Study" (PhD diss., University of Sussex, 1988).

Skegness Urban District Council Publicity Committee, Skegness Official Guide. (Skegness, Urban District Council, 1971).

Skegness Urban District Council, Skegness Official Guide 1936-1937 (Skegness: Urban District Council, 1935).

Skegness Urban District Council. (1963), Skegness. Lincolnshire. (Skegness: Urban District Council, 1963).

South London and Maudsley NHS Foundation Trust, "Improving Staff Health and Wellbeing", June 2015, <http://www.nhsemployers.org/-/media/Employers/Publications/HWB/HWBSouthLondon-and-Maudsley-June-2015.pdf> [24 October 2018].

Susan Barton, Working-class Organisations and Popular Tourism, 1840-1970 (Manchester, Manchester University Press, 2005).

Tibbalds, Francis, Making people-friendly Towns: Improving the Public Environment in Towns and Cities (London, Taylor \& Francis, 2012).

Travis, John, "Continuity and Change in English Sea Bathing 1730-1900: A Case of Swimming with the Tide," in Recreation and the sea, ed. Stephen Fisher, pp. 8-35 (Exeter, University of Exeter Press, 1997).

Wallis, Jennifer "A machine in the garden: The compressed air Bath and the nineteenth century health resorts", in Jon Agar and Jacob Ward (eds.), Histories of Technology. The Environment and Modern Britain (London, UCL Press, 2018).

Walton, John K. "Health, sociability, politics and culture. Spas in history, spas and history: An overview",

Journal of Tourism History 4:1 2012, pp.1-14.

Walton, John K. “Seaside Tourism in Europe: Business, Urban and Comparative History”, Business History 53: 6, 2011, pp.900-916.

Walton, John K. “The Social Development of Blackpool 1788- 1914” (PhD diss., University of Lancaster, 1974).

Walton, John K., "Fish and Chips and the British Working Class, 1870-1930", Journal of Social History 23: 2, 1989, pp.243-266. 
Walton, John, The English Seaside Resort: A Social History (Leicester, Leicester University Press, 1983).

Walvin, James, Beside the Seaside: A Social History of the Popular Seaside Holiday (London, Penguin Books Ltd, 1978).

White, William, History, Gazetteer and Directory of Lincolnshire (Sheffield: R. Leader Independent Office, 1842).

Whyman, John "Aspects of Holidaymaking and Resort Development within the Isles of Thanet, with Particular Reference to Margate, circa 1736 to circa 1840" (PhD diss., University of Kent at Canterbury, 1980).

Wrenn, Eddie, "Life's a Beach: Living Near the Coast is Healthier than Living Inland", 17 July 2012, $<$ https://www.dailymail.co.uk/sciencetech/article-2174179/Lifes-beach-Living-near-coasthealthier-living-inland-researchers-say.html> [18 December 2018].

York Teaching Hospital NHS Foundation Trust, "Improving staff health and, wellbeing”, June 2015, https://www.nhsemployers.org/-/media/Employers/Publications/HWB/HWBYorkJune-2015.pdf [24 October 2018].

\section{NOTES}

1. Balneotheray is the treatment of diseases by using mineral springs.

2. Vivien Breitrück and Elena Nunn, "Health and medical tourism," in The Long Tail of Tourism, ed. Alexis Papathanassis (Germany, Gabler, 2011), p. 57.

3. Peter Borsay, "Georgian Bath: A transnational culture" in Peter Borsay and Jan Hein Furnée (eds.), Leisure cultures in urban Europe, c. 1700-1870 (Manchester, Manchester University Press, 2016), p. 94.

4. John K. Walton, "Health, sociability, politics and culture. Spas in history, spas and history: An overview", Journal of Tourism History 4:1 2012, p. 5.

5. Simon Carter, "Leagues of sunshine: sunlight, health and the environment" in Virginia Berridge and Martin Gorsky (eds.), Environment, Health and History (London, Palgrave Macmillan, 2012), p. 95.

6. Jennifer Wallis, "A machine in the garden: The compressed air Bath and the nineteenth century health resorts", in Jon Agar and Jacob Ward (eds.), Histories of Technology. The Environment and Modern Britain (London, UCL Press, 2018), p. 76.

7. Jane M. Adams, "Healthy places and healthy regimens: British spas 1918-50", in Virginia Berridge and Martin Gorsky (eds.), Environment, Health and History (London, Palgrave Macmillan, 2012), p. 114.

8. The most prominent historian of British seaside resorts is John $\mathrm{K}$. Walton. His works on seaside resorts go beyond the scope of the paper and include: John $\mathrm{K}$. Walton, The English seaside resort. A social history 1750-1914 (Leicester, Leicester University Press, 1983). John Walton, Blackpool (Edinburgh, Edinburgh University Press, 1998). John Walton, The British Seaside: Holidays and Resorts in the Twentieth Century (Manchester, Manchester University Press, 2000). Other seaside historians include: John Hassan, The Seaside, Health and the Environment in England and Wales since 1800 (London, Routledge, 2016). John F Travis, The Rise of the Devon Seaside Resorts, 1750-1900 (Exeter, University of Exeter Press, 1993).

9. See for example Susan Barton, Working-class Organisations and Popular Tourism, 1840-1970 (Manchester, Manchester University Press, 2005). See also John K. Walton, "Seaside Tourism in Europe: Business, Urban and Comparative History", Business History 53: 6, 2011, pp.900-916. 
10. Edward W. Gilbert, "The Growth of Inland and Seaside Health Resorts in England”, Scottish Geographical Magazine 55: 1, 1939, pp.16-35.

11. John Hassan, op. cit.

For liminality, this concept was first used by Van Gennep in Rites de Passage (1961). It was borrowed by Shields to refer to beaches as places on the margin (liminal zones) where order is suspended. See Rob Shields, "Images of Spaces and Places: A Comparative Study" (PhD diss., University of Sussex, 1988), 192.

12. Muzaffer Uysal et al., "Quality of life (QOL) and Well-being Research in Tourism," Tourism Management 53, 2016, p. 244.

13. Studies of the development of British seaside resorts as sites of wellness are very few. The most relevant study is Stephen J. Page et al., "Case Study: Wellness, Tourism and Small Business Development in a UK Coastal Resort: Public Engagement in Practice," Tourism Management 60, 2017, pp. 466-477.

14. Winston Kime, Skeggy! The Story of an East Coast Town (Skegness, Sashell Books, 1969), p.160.

15. E. W. Gilbert, op. cit., 21.

16. James Walvin, Beside the Seaside: A Social History of the Popular Seaside Holiday (London, Penguin Books Ltd, 1978), p. 11.

See also John Alfred Ralph Pimlott, The Englishman's Holiday: A Social History (Brighton, Harvester Press, 1976), p. 52.

17. John Travis, "Continuity and Change in English Sea Bathing 1730-1900: A Case of Swimming with the Tide," in Recreation and the sea, ed. Stephen Fisher, pp. 8-35 (Exeter, University of Exeter Press, 1997), p. 7.

18. Rob Shields, "Images of Spaces and Places: A Comparative Study" (PhD diss., University of Sussex, 1988), p. 186.

19. E. W. Gilbert, op. cit., p. 23.

20. John Whyman, "Aspects of Holidaymaking and Resort Development within the Isles of Thanet, with Particular Reference to Margate, circa 1736 to circa 1840" (PhD diss., University of Kent at Canterbury, 1980), p. 110.

21. Ibid., p. 116.

22. E. W. Gilbert, op. cit., p. 23.

23. James Walvin, op. cit., p. 20.

24. John Whyman, op. cit., p. 118.

25. William White, History, Gazetteer and Directory of Lincolnshire (Sheffield: R. Leader Independent Office, 1842), 302.

See also, E. R. Kelly, Kelly's Directory of Lincolnshire and Hull (London, Kelly Directories, 1889).

E. R. Kelly, Kelly's Directory of Lincolnshire and Hull (London, Kelly Directories, 1900).

E. R. Kelly, Kelly's Directory of Lincolnshire and Hull (London, Kelly Directories, 1905).

26. Richard Gurnham, The Creation of Skegness as a Resort Town by the Ninth Earl of Scarborough, n.d. Local and Family History, Lincoln reference and local Library, L. SKEG. 9, p. 2.

27. John Alfred Pimlott, op. cit., p. 58.

28. William White, op. cit., p. 302.

29. Richard Gurnham, op. cit., p. 2.

30. John Avery, Avery's Penny Guide to Skegness and Neighbourhood, with Map (London: Avery, 1894), p. 2.

31. "Lady Scarborough has given instructions for the preparation of premises," The Hampshire Advertiser, July 11, 1885, p. 7.

32. E. R. Kelly, Kelly's Directory of Lincolnshire and Hull (London, Kelly Directories, 1900), p. 490.

33. George Dutton, Dutton's Directory of Skegness (Skegness, Dutton Printing Co, 1934), p. 6.

34. John Avery, Avery's Penny Guide to Skegness and Neighbourhood, with map (London, Avery, 1889), p. 2. 
John Avery, Avery's Penny Guide to Skegness and Neighbourhood, with map (London, Avery, 1894), p. 2.

35. "Skegness," The Leeds Mercury, June 5, 1880, p. 7.

36. Geo Ball, G, Sylvan Skegness (Skegness, Geo. F. Ball, 1932).

37. "Skegness, Lincolnshire," The Sheffield \& Rotherham Independent, March 20, 1880, p. 7.

38. "Skegness," The Leeds Mercury, June 5, 1880.

39. Anonymous, Picturesque Skegness. (C. 1900). (Skegness, Ensor \& Ball, c.1900), p. 1.

40. Abel Heywood, Guide to Skegness and Wainfleet (1925) (Manchester, Abel Heywood \& Son, 1925), p. 7.

41. "Healthy Holidays for the Worker: Conference at Skegness," The British Medical Journal: 1, 1937, pp. 876-878.

42. Eliza, "On Leaving Skegness," in Methodist Magazine, January 1, 1811, 880, database of British Periodicals

43. "Skegness," The Standard, September 10, 1885, p. 2.

44. John Avery, op. cit.

45. Ibid., p. 4.

46. Upcott Gill, Seaside Watering Places: A Description of Holiday Resorts on the Coast of England and Wales (London, L. Upcott, 1888), p. 43.

47. Upcott Gill, The Dictionary of Watering Places: Seaside and Inland at Home and Abroad. (London, Upcott Gill, 1881), p. 44.

48. Anonymous, Skegness Official Guide, 1926 L. SKEG.91. Skegness Library, p. 112.

49. Anonymous, Skegness Official Guide, op. cit., p. 21.

50. Ibid., p. 21.

51. "The weather," The Times, October 10, 1933, 16.

See also "The weather," The Times, January 19, 1938, p. 14.

52. Skegness Urban District Council, Skegness Official Guide 1936-1937 (Skegness: Urban District Council, 1935), p. 5.

53. Skegness Urban District Council. (1963), Skegness. Lincolnshire. (Skegness: Urban District Council, 1963).

See also Skegness Urban District Council Publicity Committee, Skegness Official Guide. (Skegness, Urban District Council, 1971).

54. John Beckerson and John Walton, "Selling air: Marketing the Intangible at British Resorts," in Histories of Tourism: Representation, Identity and Conflict, ed. John Walton, 88-70 (Clevedon, Channel View Publications, 2005), p. 55.

55. Alastair Durie, “A Fading Movement: Hydropathy at the Scottish Hydros 1840-1939," Journal of Tourism History 4: 1, 2012, p. 57.

56. "Skegness," The Penny Illustrated Paper and Illustrated Times, August 25, 1906, p. 122.

57. James Mackley and Jennifer Mackley, Skegness through the Years: Skegness from an Agricultural Village to a Seaside Town (Skegness, U3A, 2005), p. 29.

58. John Walton, The English Seaside Resort: A Social History (Leicester, Leicester University Press, 1983), p. 196.

59. Ibid., p. 198.

60. "One of the Brightest Original Posters," Illustrated London News, April 11, 1908, p. 546.

61. Lorna Mary Nicholls, 'Beside the Sea' Concerning the Growth of the East Coast Resort around 1870 to the Beginning of the Second World War and the People Who Helped Them to Grow" (Diss. For the certificate of Local History, Bishop Grosseteste College, Lincoln, 1978) L. 91, Skegness Library, p. 8.

62. Susan Barton, "Why We're All Going on a Summer Holiday: The Role of the Working-class Organisations in the Development of Popular Tourism, 1850-1950" (PhD diss., De Montfort University, 1999), p. 93. 
63. Susan Barton, "The Mechanics Institutes: Pioneers of leisure and excursion travel," Transactions (Leicestershire Archaeological and Historical Association) 67, 1993, p. 47.

64. "Excursion Trains and Excursionists," The Observer, August 19, 1861, p. 5.

65. Lorna Mary Nicholls, op. cit., p. 9.

66. Harold Perkin, "The Social tone of Victorian Seaside Resorts in the North-West", Northern History 11: 1, 1976, p. 182.

67. Rob Shields, op. cit., p. 199.

68. Ibid., p. 206.

69. Anthony Dingle, "Drink and Working-class Living Standards in Britain, 1870-1914", The Economic History Review 25: 4, 1972, p. 612.

70. John K. Walton, “The Social Development of Blackpool 1788- 1914” (PhD diss., University of Lancaster, 1974), p. 389.

71. "Drinking by Sunday Excursionists," The Manchester Guardian, February 8, 1937, p. 10.

72. John Murray, Handbook for Lincolnshire, (London: John Murray, 1890), p. 168.

73. David Robinson, The Book of the Lincolnshire Seaside: The Story of the Coastline from the Humber to the Wash (Buckingham: Barracuda Books Limited, 1981), p. 64.

74. Nigel Morgan and Annette Pritchard, Power and Politics at the Seaside: The Development of Devon's Resorts in the Twentieth Century (Exeter, University of Exeter Press, 1999).

75. John K. Walton, "Fish and Chips and the British Working Class, 1870-1930", Journal of Social History 23: 2, 1989, p. 243.

76. Winston Kime, Skeggy! The Story of an East Coast Town (Skegness, Sashell Books, 1969), p. 166.

77. Harold Perkin, opt. cit., p. 181.

78. Jane M. Adams, op.cit., p. 114.

79. Ibid., p. 120.

80. Áurea Rodrigues, Elisabeth Kastenholz, and Apolónia Rodrigues, "Hiking as a Relevant Wellness Activity-results of an Exploratory Study of Hiking Tourists in Portugal Applied to a Rural Tourism Project", Journal of Vacation Marketing 16: 4, 2010, pp. 331-343.

81. Definition of "wellness" from Oxford English Dictionary Online, <http://www.oed.com/view/ Entry/227459?redirectedFrom=wellness\#eid> [16 October 2018].

82. Catherine Kelly, “Analysing Wellness Tourism Provision: A Retreat Operators' Study”, Journal of Hospitality and Tourism Management 17: 1, 2010, p. 109.

83. Edward H. Huijbens, "Developing Wellness in Iceland. Theming Wellness Destinations the Nordic Way", Scandinavian Journal of Hospitality and Tourism 11:1, 2011, p. 27.

84. Liyuan Huang \& Honggang $\mathrm{Xu}$, "A Cultural Perspective of Health and Wellness Tourism in China", Journal of China Tourism Research 10: 4, 2014, p. 495.

See also see also Anthony Gonzales, Logan Brenzel, and Jennifer Sancho, "Health Tourism and Related Services: Caribbean Development and International Trade," Final report (2001), pp. 57-58.

85. Liyuan Huang and Honggang Xu. op. cit., p. 495.

86. Stephen J. Page et al., op. cit., p. 467.

87. Works on the decline of British seaside resorts are many. See for example: Tim Gale, "Modernism, Post-modernism and the Decline of British Seaside Resorts as Long Holiday Destinations: A Case Study of Rhyl, North Wales", Tourism Geographies 7: 1, 2005, pp. 86-112.

Gareth Shaw and Allan Williams, The Rise and Fall of British Coastal Resorts: Cultural and Economic Perspectives (London, Mansell Publishing, 1997).

Sheela Agarwal and Paul Brunt, "Social Exclusion and English Seaside Resorts", Tourism Management 27: 4, 2006, pp. 654-670.

88. Stephen Page et al., op. cit., p. 466.

89. Department of Health and Social Care, Prevention is better than cure: Our vision to help you live well for longer, 05 November 2018, 
<https://assets.publishing.service.gov.uk/government/uploads/system/uploads/

attachment_data/file/753688/Prevention_is_better_than_cure_5-11.pdf> [28 February 2019].

90. David MCGillivray, "Fitter, Happier, More Productive: Governing Working Bodies through Wellness", Culture and Organization 11: 2, 2005, p. 125.

91. Ibid., p. 89.

92. Joseph Opatz, Economic Impact of Worksite Health Promotion (Illinois, Human Kinetics Publishers, 1994).

93. David MCGillivray, op. cit., p. 126.

94. York Teaching Hospital NHS Foundation Trust, "Improving staff health and, wellbeing", June 2015, <https://www.nhsemployers.org/-/media/Employers/Publications/HWB/HWBYorkJune-2015.pdf>

[24 October 2018].

95. South London and Maudsley NHS Foundation Trust, "Improving Staff Health and Wellbeing", 24 October 2018, <http://www.nhsemployers.org/-/media/Employers/Publications/HWB/ HWBSouth-London-and-Maudsley-June-2015.pdf> [24 October 2018].

96. For wellbeing Saturdays see for example: Nottingham University Hospitals NHS Trust, "Excellence in Employee Wellbeing", June 2015, <https://www.nhsemployers.org//media/ Employers/Publications/HWB/HWBNottingham-June-2015.pdf> [24 October 2018].

97. Nottingham University Hospitals NHS Trust, "Excellence in Employee Wellbeing”, June 2015, $<$ https://www.nhsemployers.org/-/media/Employers/Publications/HWB/HWBNottingham-

June-2015.pdf>

[24 October 2018].

98. Department of Health, Healthy lives, Healthy People: Our Strategy for Public Health in England, Vol. 7985. (London, The Stationery Office, 2010), p. 32.

99. Ibid., p. 54.

100. Jane Atterton, "Ageing and Coastal Communities," Report for the Coastal Action Zone Partnership Newcastle-upon-Tyne, Centre for Rural Economy. Newcastle University (2006).

101. East Lindsey District Council, Skegness, Ingoldmells and Chapet St. Leonards (East Lindsey District Council, 1995)

102. Department of Health, High Quality Care for All. NHS Next Stage Review Final Report. 26-27, June 2008, <https://assets.publishing.service.gov.uk/government/uploads/system/uploads/ attachment_data/file/228836/7432.pdf> [24 October 2018].

103. Ibid., p. 32.

104. Ibid., p. 48

105. Ibid., pp. 26-27.

106. Stephen J. Page et al., op. cit., p. 467.

107. Eddie Wrenn, "Life's a Beach: Living Near the Coast is Healthier than Living Inland", 17 July 2012, <https://www.dailymail.co.uk/sciencetech/article-2174179/Lifes-beach-Living-near-coasthealthier-living-inland-researchers-say.html> [18 December 2018].

108. John Bingham, "Sea Air the Secret of Long Life as Census Shows Bexhill-on-Sea is Britain's Centenarian capital", 25 September 2012, <https://www.telegraph.co.uk/news/health/ elder/9563327/Sea-air-the-secret-of-long-life-as-census-shows-Bexhill-on-Sea-is-Britainscentenarian-capital.html> [18 December 2018].

109. For further details on the attempts to make towns people-friendly see Francis Tibbalds, Making people-friendly Towns: Improving the Public Environment in Towns and Cities (London, Taylor \& Francis, 2012) and Frey Hildebrand, Designing the City: Towards a More Sustainable Urban Form (London, Taylor \& Francis, 2003).

James Walvin op. cit., p. 11.

110. Andrew Clegg and Stephen Essex. "Restructuring in Tourism: The Accommodation Sector in a Major British Coastal Resort", International Journal of Tourism Research 2: 2, 2000, p. 77. 


\section{ABSTRACTS}

This article seeks to demonstrate the vitality of the health dimension in the growth of Skegness as a seaside resort. It shows the way changes in the medical profession, especially the use of seawaters for the treatment of diseases, contributed to the growth of seaside resorts in Britain. It highlights the way the health culture interacted with the principle of pleasure to contribute to the growth of seaside resorts. This paper also seeks to explore the potential role the National Health Service (NHS) could play in the transformation of Skegness into a wellness destination especially with the NHS emphasis on wellness as a new strategy to prevent and manage health problems, the constant inflow of an elderly generation into the resort, and an ageing population whose health needs are changing.

Cet article cherche à démontrer la vitalité de la dimension santé en tant que facteur déterminant dans le développement de Skegness en une station balnéaire. Il montre la façon dont les changements dans la profession médicale ont contribué à la croissance des stations balnéaires en Grande-Bretagne, particulièrement l'utilisation des eaux marines dans le traitement des maladies. Il met en relief la manière dont la culture sanitaire a interagit avec le principe du plaisir pour concourir à la croissance des stations balnéaires en Grande Bretagne. Cet article cherche également à examiner le rôle potentiel que le système de soins (NHS) pourrait jouer dans la transformation de Skegness en une destination de bien-être, tenant compte surtout de l'accent mis par le NHS sur le bien-être en tant que nouvelle stratégie de prévention et de gestion des problèmes de santé, sur l'afflux constant de personnes âgées dans les stations balnéaires et une population vieillissante dont les besoins en matière de santé évoluent sans cesse.

\section{INDEX}

Mots-clés: stations balnéaires, plaisir, NHS, vieillissement, tourisme de bien-être.

Keywords: health resorts, pleasure, NHS, ageing, wellness tourism

\section{AUTHOR}

\section{MOHAMED CHAMEKH}

Ibra College of Technology 